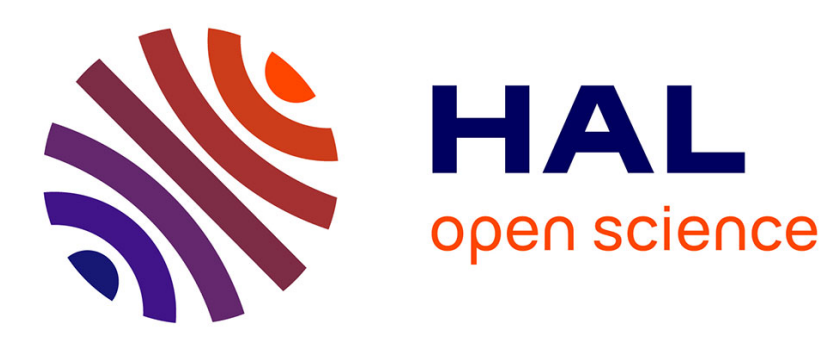

\title{
An innovative observatory of polar expedition projects: An investigation of organizing
}

Géraldine Rix-Lièvre, Pascal Lièvre

\section{To cite this version:}

Géraldine Rix-Lièvre, Pascal Lièvre. An innovative observatory of polar expedition projects: An investigation of organizing. Project Management Journal, 2010, 41 (3), pp.91-98. hal-00787124

HAL Id: hal-00787124

https://hal.science/hal-00787124

Submitted on 11 Feb 2013

HAL is a multi-disciplinary open access archive for the deposit and dissemination of scientific research documents, whether they are published or not. The documents may come from teaching and research institutions in France or abroad, or from public or private research centers.
L'archive ouverte pluridisciplinaire HAL, est destinée au dépôt et à la diffusion de documents scientifiques de niveau recherche, publiés ou non, émanant des établissements d'enseignement et de recherche français ou étrangers, des laboratoires publics ou privés. 


\title{
An Innovative Observatory of Polar Expeditions Projects: An Investigation of Organizing
}

\author{
Géraldine Rix-Lièvre \\ Clermont University, \\ Blaise Pascal University \\ UFR STAPS \\ EA 4281 PAEDI \\ BP 10448, F-63000 Clermont-Ferrand, France \\ Mail : geraldine.rix@univ-bpclermont.fr \\ Tel : +334734078 55 \\ Pascal Lièvre \\ Clermont University and ESC Clermont Graduate School Management \\ EA 3849 CRCGM \\ BP 10448, F-63000 Clermont-Ferrand, France \\ Mail : PascalLievre@orange.fr \\ Tel : +33473842914
}

\begin{abstract}
The purpose of this article is to present a methodology for investigating projects of polar expeditions: in situ, in vivo and in extenso. It is a new kind of qualitative methodology in that, classically, this type of method mostly focuses on "ways of saying” (Hlady Rispal, 2002), whereas we concentrate on "ways of doing" (Lièvre \& Rix, 2009). The aim is to study the actuality of the collective action of organizing in its totality. It is guided by the description of "organizing" as defined by Weick. This case is built from information gathered by two actors engaged in the expedition, each one collecting data in a specific perspective. The first data collection was dedicated to collective dimensions. The multimedia logbook is filled in by a researcher in a posture of observant participation, relying on paper or video traces regularly collected throughout the project. These traces are then shaped to make a narrative. The second data collection was dedicated to more individual practices and therefore centered on individual members of the expedition at specific moments. The Device for Objectifying Situated Practices relies on two videos of the situation, one from an outside point of view, the other one using an embedded camera in order to record from a standpoint close to the actor's one, and on an interview with the actor using the second recording. The method allows to objectify the tacit knowledge implemented by the actor in a done situation, and to shape it in a chronological statement.
\end{abstract}

Keywords: methodology, project, organizing, logbook, subjective re situ interview, polar expedition 


\section{Introduction}

The purpose of this article is to present a methodology for investigating polar ski expeditions: in situ, in vivo and in extenso. This observatory looks at how the actors organize themselves in an extreme environment. It is a new kind of qualitative methodology in that, classically, this type of method mostly focuses on "ways of saying" (Hlady Rispal, 2002), whereas we concentrate on "ways of doing" (Lièvre \& Rix, 2009). This observatory's aim is to study the actuality of the collective action of organizing in its totality. It is guided by the description of "organizing" as defined by Weick. It endeavours to study the ways by which the organization is creating itself by attempting to confront both the problems relating to studying the activity and the taking into account of the individual and collectives dimensions of organizational dynamics.

The term "organizing" needs clarification. In 1969, Karl Weick proposed in his founding work, The Social Psychology of Organizing, a major shift in the investigation of organizations, symbolised both by the use of the term "organizing" rather than "organization," and by the desire to give organized collective action a perspective that is not just sociological (collective) but also psychological (individual), which he qualified as an approach in terms of social psychology. Organizations were to be observed as processes being developed. In Weick's own words (2003), it is necessary to understand "how organisational life unfolds" in situation in each case. How do the actors constructindividually and collectively - the meaning of their action, and according to which organizational dynamic?

To answer the difficult question of the passage from the individual to the collective and vice versa, we propose an observatory comprising two complementary investigatory tools: the multimedia logbook (MLB) with a collective viewpoint, and the situated practices objectifying system (SPOS), focused on each individual—each depending on the personal and distinct commitment of a researcher. So the system as a whole depends on the simultaneous presence of two researchers.

This observatory results from reflection in progress since 2000 on methodology in the framework of a research programme investigating extreme situations management centred on polar expeditions. A polar expedition is seen as "exemplary" project management in a changing, uncertain and risky environment. Within this framework, a polar expedition is considered a project management (Garel, 2003) ideal for research purposes, insofar as (1) in a context of this type the phenomena are more easy to interpret, as each actor's logic is pushed to the limit, and (2) it allows participating observation as close as possible to the experienced situations.

In the first place, we shall list the obstacles to study organizing. Then we present the observatory, specifying each of the tools developed as well as the ways in which they are coordinated and complement one another. Lastly, we give an example in order to show how this observatory has been implemented in the context of a Labrador expedition, before showing how our data are treated in relation to the subject of polar bear risk management.

\section{The Obstacles to Be Overcome to Investigate Organizing}

Before presenting the methodology constructed to investigate the running of a polar ski expedition as organizing, we return to the inherent limits to understanding activity through observation and speech, respectively, which justifies the development of a special observatory. We highlight first of all the insufficiency of observation for understanding the practices. We shall then demonstrate the limits of speech on the activity as a way to understanding it. 


\section{Limits of Observation}

Once the paradigmatic change in social sciences had been completed (Dosse, 1995), actions could no longer be thought of without considering their meaning. Behavior is considered as "an object of study with two faces-a public one of observable behaviour and another private and unobservable" (Vermersch, 2004, p. 36); consequently, "to be relevant the description of the activity and the situation must not be monopolised by the scientific observer [... but must be] effected from the point of view of the actor's internal dynamics" (Theureau, 2000, pp. 182-183). Thus, the actor is no longer a mere object of study, but has become a subject; far from being "a cultural idiot" (Garfinkel, 1967), he is considered as an intelligent, rational and, at times, sensitive subject with a subjectivity worthy of enquiry. So even if observing the organization in situation is indispensable, it is not sufficient for documenting practices: constructing data of another nature appears necessary.

The actors are then incited to provide words on their actions and activities from their own points of view, and on how they see what they do. They may be invited to account for their progress, their successes and failures, their qualities and difficulties, or their emotions. All their verbalizations can be used to document the activity, but do not clarify it overall. The actor develops, depending on the context and to whom he is speaking, different ways of saying his action: he explains it, justifies it, evaluates it, or describes it. His verbalizations, more or less spontaneous, differ in nature, each relating in a particular way to his action. So in order to understand the practices of polar expeditions, it is necessary to distinguish the different kinds of verbalizations the actors produce about their activity and to propose different utterance contexts that help one understand, on the one hand, the collective action's dynamics, and on the other, what, from the subject's point of view, is the basis of his action.

\section{The Limits to Discourse for Studying the Activity in New Utterance Contexts}

Indeed, as Lahire (2002, p. 391) following Bourdieu (1990) emphasized, during social interaction or sociological interviews, the actors are led "to talk about themselves and to select in their past the traits they judge to be salient." Consequently, the discourse produced is similar to a "verbal construction of oneself by oneself [which] is the product of narrative work based on the observation of oneself by oneself and by others" (Lahire, 2002, p. 392). These verbalizations, then, resemble an emplotment (Ricœur, 1983): an ordering that presupposes the introduction of a logic or causality in the events' succession. They reveal the coherence the actor confers on his action after the event, what he wants another to see, or what lets him make his activity seem rational to another. In this way especially, they allow the identities of the individual constructs to be grasped (Dubar, 1991), the knowledge he mobilizes to justify his practices to be brought to light, the goals he has set himself to be studied. On the other hand, they do not appear to be able to document the rationality of the action in the situation, that is, the logic that governs it as it actually takes place.

This explanatory ordering does not coincide with the rationality in action. "Action is a form of knowledge in its own right ... it exists, it functions, it has goals and it reaches them-without necessarily being conceptualised" (Vermersch, 1996, p. 72). The logic governing the action's running is an actualizing knowledge, an incarnate signification, a knowledge at work that only manifests itself in, through, and during the action. Accordingly, its content may be termed implicit insofar as it is still not consciously conceived; action, therefore, does not have a rationality of the same nature as discourse. On the one hand, Acting is characterized by its efficacy, its relevancepractical and effective - at a given moment: it is a performance, an implementation. On the other hand, Saying is demonstration and presentation; it is characterized by its coherence and its general significance. A real epistemological rupture exists between acting and saying. Faced with the incapacity of reducing practice to a discourse, the researcher is confronted with a dilemma: either give up treating action as an object of study insofar as scientific progress can only come from a discourse; or, while accepting action's irreducible nature and the 
impossibility for verbalizations to cover it, attempt to understand and/or explain by taking an interest in the relations between the actor's verbalizations and action. In the latter case, the researcher must examine the production conditions of the verbalizations documenting the acting, that is, the logic of the action, the actualizing knowledge at work, the way in which the actor constructs and lives his situation.

Based on these two facts, the observatory we propose makes a point of combining both levels: data obtained from observation and discourse enable the way the actors live and act during the expedition.

\section{Presentation of the Observatory}

As we pointed out in the introduction, the observatory's aim is to study organizing by trying to deal both with the problems relating to studying the activity we have highlighted and with considering the individual and collective dimensions of the organizational dynamics. Toward these ends, the working of the observatory depends on two researchers each having his own objective, standpoint, and investigatory tools. Both take part in the same expedition - from the idea for the project, including the period of preparation and the expedition itself, right up to the homecoming - and are embedded in the team. We present here each researcher's work and investigatory tools in turn before highlighting their complementarity.

\section{Giving an Account of a Reality Shared by the Collective: The Multimedia Logbook}

The stance of the first researcher - an experienced participant in polar ski expeditions - is that of an actor: just like any other expedition member he has his responsibilities - the tent, the stove, anti-bear safety, making progress, and so forth-he acts, intervenes, in part leads the expedition. In anthropological terms this way of investigating practices in situation might be qualified as "observing participation" as meant by Junker (Peretz, 2004), who emphasized that a researcher's observation is subject to his activities as a participant. In fact, this does not suppose, as this author implies, that the observation takes place without the other team members knowing about it: the actors are informed of the study's methods and purposes, take part willingly, and receive the final reports. David et al. (2000) speak of direct participation to categorize this type of participating observation. This still means the actors expect the same commitment from the researcher as they do from one another-both physically and morally. This level of commitment—with a touch of material construction into the bargain — can only be given by a researcher, especially during an unassisted polar ski expedition and so in a dangerous environment, if the researcher has a certain expertise. On the other hand, the notion of observing participation insists on a second consequence of a high level of commitment to the activity - the need to intervene. The researcher cannot aim for an illusory neutrality-the passive observation of a so-called "natural" situation (Berry, 2000; Plane, 2000). In this way, the researcher not only takes part in all of the group's activities and choices, but also gives the group the benefit of experience with tools to develop, monitor, and adapt the project, and intervenes at any moment to help it progress well. This observing participation enables the researcher to develop a certain insider view in relation both to the group and its activities. Seeing from the inside is indispensable for approaching the collective processes for decision making, strategic reflection, and project management.

Armed with an inside approach to the workings of a collectivity engaged in achieving a project, and standing in an actor's shoes, the researcher must develop investigatory tools that enable building a record of the group's activity, despite being fully involved. Throughout the expedition-from its initial idea, through the constitution of the team, the search for sponsors, the choice of equipment, the moments of preparation, the actual expedition, until the return to France, and at any moment - the researcher must be able to establish and/or preserve various items recording what happens inside the collectivity. To achieve this continuous record, a multimedia logbook (MLB) was developed, 
which makes use of several media and takes different forms depending on the project's phases. During the team constitution phase, the MLB includes the e-mail messages between the various parties; it brings together the notes taken by the researcher during the meetings and their sound recordings; it also makes use of video, since during ski trekking the researcher must keep a record of the expedition's daily progress-especially of how the group organizes itself — as well as particular events. Combining various types of materials, it ultimately corresponds to the researcher's point of view as the project progresses.

From this logbook and a work of reflection on his or her own practices—a real first-person approach (Vermersch, 1999) - the researcher, in the form of a film and/or in writing, can produce an account of the expedition's running. In order to construct from the logbook - and thus from the data resulting from experience as an actor inside the groupa scientific body of knowledge from a constructivist point of view, the researcher must, post factum, develop a reflection so as to explain this experience and thereby the way the observations were worked up (Le Moigne, 1995). This reflection can be related to the indispensable reflexivity of the researcher that various authors have emphasized in anthropology or more broadly in social sciences. The resulting explicitness not only allows the researcher to give an account of methods of investigation, but also enables taking a distance from his or her own experience. In this way he or she acquires the ability to produce an account detached from subjectivity as an actor to be accepted by all the members of the team. This account thus corresponds to making diverse elements and events cohere into a story that gathers the various phases of the expedition by joining them logically together (Ricoeur, 1983).

This account relating a reality shared on the expedition constitutes, on the one hand, the corpus on the basis of which the researcher can question the modes of organization from a logistic angle or from the project management point of view, focus on a particular operation such as the recruiting methods, or follow the role of the leader throughout the project. On the other hand, it constitutes a source of information for any practitioner: by acceding to the actual real life working of a collective's organization, practitioners can draw lessons for their own projects.

\section{Entering Each Actor's World of Practices: The Situated Practices Objectifying System}

If the first researcher's investigations are oriented toward the collective side of the organization, the second's aim is to understand the individual and spontaneous practices of each member of the team in situation. The job is, at particular moments, pitching a tent, progressing for an hour, or attending a preparatory meeting in order to understand what an actor is doing both objectively and subjectively.

Accordingly, the second researcher is embedded in the team, not as a teammate like the first, but as a novice in polar ski expedition who wants to learn what each team member does, as an observer who follows the group in its path and contributes to all the collective tasks without taking any responsibility or decision. Compared with the first researcher's observing participation, the second's stance should be described rather as participating observation. The role is not to intervene in the actors' practices but above all to investigate them (Peretz, 2004). If participation in the activity of the group amounts to no more than following it to understand what is happening, it is not merely in order to recover, exhaustively and with neutrality, a "given reality." Besides, as Favret-Saada (1977) pointed out, even the would-be external observer takes part in the situation studied, both through the way the observer looks at it and through the way the others look at the observer. So the inversion of the terms means that in situation, this researcher stands back more from the group. On the one hand, this stance leaves him more time for his observations, for taking notes in situ, as well as setting up various investigation systems. On the other, it spares him from having to take position in relation to the members of the group; in this way he can still share the intimacy of their own experience with each of the actors after the event without their feeling judged or compared. 
During his participating observation, the researcher is able — thanks to a relative distance to the group - to build up various observation data on the practices of each member of the team. However, to understand these practices, the action's implicit, personal, and significative aspect, going beyond what is observable, needs to be approached, that is, the way in which each actor lives his or her situation and acts at a particular moment. Insofar as, for each individual, his or her way of being, living, acting in a particular context is above all in action and remains broadly pre-reflected, it becomes necessary to set up a system that encourages and helps the actor to make his or her practice explicit. With this end in view, we have developed a new methodology: the subjective re situ interview. Largely inspired from selfconfrontation (Theureau, 1992) and the explication interview (Vermersch, 1996), this system focuses on the running of the action by at the same time mobilizing observation and data relating to the actor's subjectivity. It has three more precise objectives: the first is to focus this explication effort of the actor's on a moment the researcher chooses; the second is to relate the explication verbalizations to an act already documented and actually having taken place, thereby checking the relation of the discourse to the act and documenting the act from different types of materials; the third is to stay as close as possible to the actor's way of being in the situation.

Concretely, the system set up for each moment investigated consists, in the situation, in filming (1) an actor's behavior in its context, and (2), thanks to an on-board camera, a point of view close to the actor's in action, a situated subjective perspective. After the event - that is, after a meeting, at the end of a technical weekend, returning from a preparation trek-in turn, the actors are asked during subjective re situ interviews. Each interview, carried by the researcher, consists of putting an actor back in a particular moment by using the recording of his situated subjective perspective, so as to induce him to make explicit his way of being at that moment. In this way the subjective re situ interview represents for the researcher a tool that enables approaching what he or she experienced during the event that the video is showing. Standing off from the group and its in situation activities, the researcher enters, after the event and in turn, the world of the practices of each actor.

Finally, to document each investigated moment, we can use, at the same time, the actor's verbalizations, which show, subjectively, how he or she lives the situation, and two recordings made in situ of his or her behavior and situated subjective perspective. These different types of materials, fairly subjective and fairly objective, are harnessed together to reconstruct the process of the action. Thus, we are able account for and understand the singular, spontaneous, and situated practices of the different members of the team.

\section{What Complementarity for Understanding the Organizing?}

Having set out the stance of each of the researchers, we shall discuss the interest of this dual investigation of a polar ski expedition seen as an organizing. In a positivist epistemology, placing two researchers on the same framework to study the same actors has no sense, except to corroborate the reliability of the observation of a given reality. From a constructivist point of view (Le Moigne, 1995), this possibility represents the opportunity to develop two different perspectives differing in several dimensions within a single research program: (a) Novice-Expert, (b) ActorFollower, (c) Individual-Collective.

The account of the first researcher highlights, in a reconstruction of the running of the expedition accepted by all, how the collective works. In parallel, the materials constructed by the second researcher enable us to grasp the practices of each of the actors and what motivates them in situation. Thus, the observatory we propose places the researcher's relations to his or her terrain —or more precisely to the actors' terrain —at the heart of the construction of the data. The fact that every researcher participates in the situation being studied no longer then appears as a bias, but as the basis for being able to construct different data (Berry, 2000; Favret-Saada, 1977; Girin, 1990; Plane, 
2000). The postulate is the following: the stance of each researcher in the field allows the researcher to document, in his or her particular interaction with the actors, different facets of the organizing.

Thus, both these systems, far from attempting to grasp a reality exhaustively, seem complementary and necessary for understanding a polar ski expedition as an organizing. Considering that the activity of the collective is more than the sum of its individual practices, understanding how a group organizes itself is impossible if these practices only are studied. Inversely, approaching the genesis of a collective activity - that is, what emerges from its interactionsseems impossible without taking a look at each actor's acts and their cognitive, affective, bodily motivations. Only by making the one echo the other can an organizing be understood-in this case, as we shall show in the following part, managing bear risk within a polar ski expedition.

\section{The Organization Face-to-Face with the Management of a Risk}

In order to show how the various data constructed within the observatory enable the organizational dynamic to be understood, we present the products of an investigation centred on managing the risks connected to the presence of polar bears during a Labrador expedition. We shall present the yield from each system successively-the MLB and the SPOS - before showing how they are combined together so as to, it seems to us, understand the organizing in relation to the danger represented by the polar bears, an important factor in the success of a polar expedition.

\section{MLB Data Giving Information about Polar Bear Risk Management}

We cannot report on the expedition logbook proper here, for obvious reasons of space-it comprises some 20 pages - and relevance to the issue with which we are concerned. We shall only use a few extracts from the MLB that document the question, particularly, the account of the various exchanges about "bear" safety and a narrative of an event during the expedition.

The Account of the Various Exchanges about "Bear" Safety

During the preparation phase, a meeting was organized with the different team members. Michel, the expedition leader, chaired the meeting; the second point on the agenda, which the MLB records, is what concerns us here.

The second problem to be discussed during this meeting was the protection against polar bears. Opinions were divided. Everyone related his various experiences with polar bears and the various techniques used. In any case, you bring a rifle; it is compulsory on this kind of expedition. The next issue was whether to have two rifles—one per tent. "No, it's too dangerous," Michel declares. "There must be only one rifle and I must have it." And for safety during the night-what do we do? Many possibilities exist: a night watch, alarm system round the camp ... Michel settles the problem by proposing to take dogs: a technique used during a previous expedition, although he himself had not been in charge of them at that time. The others have never used dogs and are sceptical. Dogs can also attract bears. Michel makes the point he and Gilles will look after the dogs during the expedition. The matter was settled. The decision was made to buy two dogs on the spot.

The choice finally made by Michel, the expedition leader, relies on two tools: the presence of dogs throughout the expedition to deter the bears or, in the last resort, to warn that they are coming, and a rifle to be used as a weapon should the animal attack. Michel and one of the team members will take care of the problem of anti-bear protection. He will have the weapon and manage the dogs with his teammate. 
In his MLB, the researcher recorded a video commentary in which he recounted the event of the day: the loss of the dogs. From this recorded commentary and written notes relating to this period, the researcher constructed the narrative of the expedition, from which we reproduce an extract here:

But in the early afternoon the wind blows still stronger and Michel does not manage to warm up his finger. The team gets worried. Pierre decides to pitch camp immediately so Michel can get warm. The next day Michel sets off as though it is nothing. He goes out in front with a dog without saying a word. The others follow him and then catch up with him. They arrive at a tricky passage on a frozen river requiring crampons to be put on. The dogs are frightened-they are sliding. Michel and Gilles, supposedly in charge of the dogs, are in front. In fact, Pierre and his friend retrieve the dogs. Slow progress is made. They reach a break in the ice slope: a ditch of 2 to 3 meters. Pierre starts out slowly with a dog and slips. In order not to injure the dog he unleashes it and sends it in the direction of Michel waiting below. Instead of rushing to catch it Michel declares: "There's no need to bother about the dog! It won't go far." Seeing the first dog running away, the second struggles and manages to get away. The dogs have gone. They are not going to come back. Tension between teammates after this dog incident. The team worries about not having security against bears any more. Michel minimizes the problem and does not seem to be bothered. Pierre has brought safety equipment from other expeditions with him: rocket flares, wire, and rubber bands. He puts together an anti-bear enclosure to protect the camp from unwanted polar bears during the night. In the morning, Michel starts the day without giving any instructions.

Michel had not seemed to pay much attention to looking after the dogs and had made many errors of judgment leading to their definitive loss. Faced with these various omissions the other team members reacted intensely and tried to cobble together a warning system with rockets to surround the camp every evening. Michel seemed unconcerned by the problem.

\section{The Formalization of a Practice}

Data produced by the SPOS enable us to account for how the bear risk was experienced by Michel at various moments. At various critical phases during the trek, Michel was equipped with the remote lens camera and the researcher, walking all the while, filmed what he was doing from the side with a wide angle. The subjective re situ interviews were carried out in France after the trek.

We present in Table 1 the data about a moment of Michel's progression. In the first column, we describe the context using video recordings of Michel's behavior and his situated subjective perspective. The idea is to expose what can be seen and/or heard at that moment while limiting the interpretative intrusions. This description is not intended to be exhaustive: it is still possible to clarify Michel's behavior and events. It does, however, inform what actually happened, enabling anyone who does not have the videos and did not experience this moment of progression to follow the course of the practice. In the second column, part of the subjective re situ interview about the same moment is re-transcribed; it is through this dialogue that the researcher can little by little approach what the explorer experiences, what is significant for him at that moment, what compels him, what affects him, what matters to him, and so forth. With these different data, we attempt to formalize Michel's practice at that particular moment of progression, while taking into consideration both his experience through his explications and what he actually did. Thus, this formalization results from a synthesis of descriptive data and verbalizations. It is the researcher's narrative 
construction that presents the course of Michel's practice, especially how the situation becomes risky for him as he progresses. It describes step by step what Michel is doing and what is making sense for him as it happens.

\section{Table 1: Formalization of Michel's Practice in Relation to the Polar Bear Risk at a Given Moment}

In this way we formalize Michel's practice at various moments. These formalizations make it possible to highlight how bear risk becomes actual for Michel in situation: the risk presented by bears during the expedition only exists when it is manifested by visible traces of a bear's presence; it is only in this precise context that he implements a safety system associated with the rifle he has.

\section{Ways of Managing Polar Bear Risk}

The combination of two types of reports makes it possible to give an account of the actual operating of the expedition's organizational life as related to bear safety. Two examples follow:

The formalizations of Michel's practice show bear risk is only actual for him when connected to identified places or specific traces and that, in these cases, the only real protection is the rifle of which the probable use imposes a certain order of walking. It then becomes understandable why Michel is so unconcerned about managing the dogs in situation, why for him their loss constitutes no danger, and why he makes no effort to make and install another security system. It is not carelessness; it makes no sense insofar as the danger has no meaning for him in such cases.

Although during the preparation phases, Michel's words and choices concerning protection against the bears implicate the organization, the very way he handles the risks in situation is quite different from this planning. This difference throws new light on the tensions observed within the collective and on how the organization adapts concerning this issue.

These two examples make it possible to illustrate to what extent dovetailing, on the one hand, data relating to collective functioning, and on the other, individuals' logic of action, is of interest for understanding an organizing.

\section{Conclusion}

Looking at the organizing with a Weickian—-that is, deliberately "interactionist"-perspective, the combination of the logic of each individual in the situation with, in return, that of the collective on each individual is what enables the organizational dynamic to be accounted for. From a theoretical point of view we envisage that the possibility of accounting for the organizing in its total actuality is located at a "meta" level in relation both to the collective logic of action as documented by the MLB and to each individual's logic of action as shown by the formalizations. This theoretical orientation generates a specific comprehension of the organizing. The comprehension of the expedition's polar bear risk management produced by combining the results of the different systems (MLB and SPOS) is unlike that that might be produced by either separately. Going by the account produced by the MLB, we might conclude that the expedition leader was negligent in managing the dogs and the bear risk. Whereas the formalizations produced by the SPOS show that the safety systems only made sense for him when the bear's presence was evident.

As for the issue of the cumbersome nature of such an observatory, it should be seen against the specificity of the qualitative method used centred not on "ways of saying" but on "ways of doing." The observatory enables the collective activity to be studied in its organizational dynamic from various types of data-both observations of activity in situation and the actors' more or less formal verbalizations. In this way it aims not to reduce the study of the activity to a study of discourse about the activity, while taking into account how the actors live their situations 
and describe them. The advantages and limits of this observatory should be seen in relation to what it reveals: the ways in which the organization is making itself.

To conclude, we must discuss the issue of how to use this type of method in more classic managerial situations. The tool developed here for use in a polar expedition context can obviously be used to cover more usual collective management practices, in more classic organizations-we could even say a fortiori-given the technical problems of the cold, the snow, and so forth. But at the same time, accepting such an intrusion into everyday working life presupposes considerable preparatory work, and a relation of trust between the researchers and the actors of the organization, which is far from a matter of course and has to be built up over time. Though the system does partially transform the situation, it must in no case disturb it: the activity must retain the upper hand. At the outset, the different uses of the materials gathered in the organization should also be made clear to the various actors of the organization. Returning data produced by an observatory of this type gives a substantial increase to transparency in various management situations - potentially a major unbalancing factor in terms of power and strategy. At the same time, are not the industrial relations prevailing in this type of operation those needed nowadays in an innovative, learning, and creative enterprise working within a knowledge-based economy (Foray, 2004)?

\section{References}

Berry, M. (2000). Logique de connaissance et logique d'action (Logic of knowledge and logic of action), Cahier de recherche de l'Essca, $\mathrm{n}^{\circ}$ 7, pp. 3-58.

David, A. (2000). Logique, épistémologie, méthodologie en sciences de gestion : trois hypothèses revisitées (Logic, epistemology, methodology in management science: three hypotheses revisited). In A. David, A. Hatchuel, \& R. Laufer, Les nouvelles fondations des sciences de gestion (The new foundations in management sciences), (pp. 83-108). Paris, France: Vuibert.

Dosse, F. (1995). L'empire du sens. L'humanisation des sciences humaines (The empire of sense. The humanization of Humanities). Paris, France: Edition La découverte.

Dubar, C. (1991). La socialisation : construction des identités sociales et professionnelles (Socialization: social and professional construction of identities). Paris, France: Armand Colin.

Favret-Saada, J. (1977). Les mots, la mort, les sorts (The words, death and spells). Paris, France: Gallimard.

Foray, D. (2004). The Economics of knowledge. Cambridge MA, London, England: The MIT Press.

Garel, G. (2003). Le management de projet (Project management). Paris, France: La Découverte, Collection Repères.

Garfinkel, H. (1967). Studies in ethnomethodology. Englewood Cliffs, New Jersey, USA: Prentice Hall.

Girin, J. (1990). L'analyse empirique des situations de gestion (Empirical analysis of management situations: elements of theory and method). In A. C. Martinet, Epistémologie des sciences de gestion (Epistemology and management sciences ) (pp. 141-182). Paris, France: Economica.

Hlady Rispal, M. (2002). La méthode des cas. Application à la recherche en gestion. (The case method. Application to management research).Bruxelles, Belgium: De Boeck Université. 
Lahire, B. (2002). Portraits sociologiques. Dispositions et variations individuelles (Sociological portraits. Provisions and individual variations). Paris, France: Nathan.

Le Moigne, J. L. (1995). Les épistémologies constructivistes (The constructivist epistemologies). Paris, France: PUF.

Lièvre, P., \& Rix-Lièvre, G. (2009). Mode d'interprétation des matériaux issus d'un observatoire de l'organisant (Analysis of data from an in vivo observatory of organizing). Revue Internationale de Psychosociologie, $X V(35), 161-178$.

Peretz, H. (2004). Les méthodes en sociologie. L'observation (The methods in sociology. The observation). Paris, France: Edition La découverte.

Plane, J.-M. (2000). Méthode de recherche-intervention en management (Method of research-intervention in management science). Paris, France: L'Harmattan.

Ricœur, P. (1983). Temps et récit. Tome 1 : L’intrigue et le récit historique (Time and Narrative. Volume 1: The plot and the historical narrative). Paris, France: Seuil.

Theureau, J. (1992). Le cours d'action, analyse sémiologique : essais d'une anthropologie cognitive située. (The course-of-action: semiological analysis. Essay on situated cognitive anthropology). Berne: Peter Lang.

Theureau, J. (2000). Anthropologie cognitive et analyse des compétences (Cognitive anthropology and analysis skills). In L'analyse de la singularité de l'action (Analysis of singularity of action) (pp. 171-211). Paris, France: PUF.

Vermersch, P. (1996). L'entretien d'explicitation (Interview of explicitation). Paris, France: ESF.

Vermersch, P. (1999). Pour une psychologie phénoménologique (Towards a phenomenological psychology). Psychologie Française, n $44-1,7-18$.

Vermersch, P. (2004). Prendre en compte la phénoménalité : propositions pour une psycho phénoménologie (Consider phenomenality: proposals for a psychological phenomenology). Expliciter, ${ }^{\circ}{ }^{57,}$ 35-45.

Weick, K. E. (1979). The social psychology of organizing. New-York, USA: Random House.

Weick, K. E. (2003), Préface (Preface). In B. Vidaillet, Le sens de l'action (The sense of action) . Paris, France: Vuibert. 
Table 1: Formalization of Michel's practice in relation to the polar bear risk at a given moment

\begin{tabular}{|c|c|}
\hline Description of the context & Explication of the actor \\
\hline $\begin{array}{l}\text { We have arrived at the end of a fjord. } \\
\text { Two team members are walking ahead of Michel; they } \\
\text { are } 50 \text { meters away. I am walking on his left slightly } \\
\text { behind him. } \\
\text { Michel looks alternately just in front of him, then at the } \\
\text { right bank that we are walking along. }\end{array}$ & $\begin{array}{l}\text { Researcher: So, you're looking for something in } \\
\text { particular ... } \\
\text { Michel: Here, I'm looking at the coast ... } \\
R: \text { For you, there is danger there? } \\
M: \text { The danger is on the coast ... } \\
R: \text { OK ... Is it a risk, is it danger, what is it at that } \\
\text { moment? } \\
M: \text { There is a risk, not in ... which is not } \\
\text { inconsiderable ... I know that at this spot there is a den, } \\
\text { that there are dens because I've seen them ... I know } \\
\text { there's a seal that got itself killed, I know because there } \\
\text { are bear tracks ... So there are all the indications that } \\
\text { point to ... }\end{array}$ \\
\hline $\begin{array}{l}\text { He stops and points to the right bank with his stick, and } \\
\text { as I arrive next to him, he says: "You see, these are } \\
\text { crappy areas because you can have a bear hiding out } \\
\text { inside there that suddenly comes out..." } \\
\text { Then starting to walk and looking at his fellow team } \\
\text { members, he continues: "That's why I told them to not } \\
\text { stay in front of the gun, but ... They didn't listen to } \\
\text { me." He continues to walk towards the end of the fjord } \\
\text { and looks frequently just in front of him, at the other } \\
\text { team members and the coast. }\end{array}$ & $\begin{array}{l}R: \text { So you're telling me that, at that moment, that's } \\
\text { what really matters? } \\
M: \text { You see, I'm saying it again ... } \\
R: \text { Does that bother you there? That they (the other } \\
\text { team members) didn't listen to you? Are you saying it } \\
\text { to me again? ... } \\
M: \text { No, it doesn't bother me, but I'm saying, they're } \\
\text { wrong ... } \\
R: \text { OK... } \\
M: \text { You see, I'm saying, that is the kind of crappy area } \\
\text { for those reasons... I'm telling them not to do it, to not } \\
\text { stay in front of me, they stay in front, let them go to } \\
\text { hell! }\end{array}$ \\
\hline \multicolumn{2}{|c|}{ Formalization of the practice } \\
\hline \multicolumn{2}{|c|}{$\begin{array}{l}\text { At the end of this fjord, Michel knows that there are bears: he has already seen dens at this spot. The tracks in the } \\
\text { snow and the remains of a seal confirm this possibility. While walking on, he is on the lookout. A bear can be } \\
\text { hidden behind a block of ice: we might see it at the last second, when he charges. You have to be ready to react. } \\
\text { The gun is on Michel's pulka. For everyone's safety, it is better to stay in a group and behind the gun. Michel } \\
\text { mentioned that to everyone, but the others continue to stay in front, which annoys him. While walking at his own } \\
\text { pace, he remains attentive. }\end{array}$} \\
\hline
\end{tabular}


Géraldine Rix-Lièvre holds a PhD in Sport Sciences. She is senior lecturer at Blaise Pascal University (ClermontFerrand, France), and a member of the research group "Corporeal Experience and Practices" of the PAEDI. She studies the embodied dimensions of practices, especially those of polar expeditions and of refereeing situations, and has developed patented new methods to make these dimensions of human experience explicit. She has contributed to Encyclopedia of Case Study Research (Sage Publication) in 2009, and to several reviews: Intellectica, no. 38 in 2004 and Knowledge Management Research and Practice, no. 6, in 2008.

Pascal Lièvre holds a $\mathrm{PhD}$ in Production Economics from the University of Lyon-II, he is professor (HDR, University of Aix-Marseille-II) in Management Science at the Clermont University and ESC Clermont Graduate School of Management. He has been a lecturer in Logistics to Graduate and Postgraduate students since 1996. He also works as a researcher for the CRET-LOG in Aix-en-Provence, and for the Centre de Recherche Clermontois de Gestion et de Management (CRCGM). Since 2000, he has been in charge of a research program into the management of extreme situations dealing mainly with Polar expeditions. He has directed or co-directed five books on management and logistics, amongst which in 2006, Management de projet, les régles de l'activité à projet (ed. Hermes \& Lavoisier), 2007 , La Logistique (ed. La découverte). 